\title{
The Performance of Agricultural Extension Workers in Utilizing Cyber Extension in Malang Raya Region
}

\author{
Sabir $^{1 *}$, Sugiyanto ${ }^{2}$, Keppi Sukesi ${ }^{2}$, and Yayuk Yuliati ${ }^{2}$ \\ ${ }^{1} \mathrm{PhD}$ Student, Doctoral Program of Agricultural Science, University of Brawijaya, Indonesia \\ ${ }^{2}$ Doctoral Program of Agricultural Science, University of Brawijaya, Indonesia
}

(Received December 5, 2018; Accepted December 18, 2018; Published December 27, 2018)

\begin{abstract}
Cyber extension is a system of agricultural extension information through the internet media to support the provision of extension materials and agricultural information for extension workers. The existence of cyber extension is expected to support the performance of agricultural extension workers. This study aims to describe the implementation of cyber extension, describe the extension worker in the utilization of cyber extension and formulate the improvement efforts of extension worker in cyber extension in Malang Raya area. The research method used a combination of quantitative and qualitative (concurrent mixed method). This study revealed that three regions did not have administrator or manager of cyber extension. In addition, the results of descriptive analysis showed that the performance of agricultural extension-based cyber extension in Malang Raya region is still very low. Several efforts that can be taken by the government are to facilitate the technical implementation unit of extension with cyber extension equipment, the provision of financing budget and the socialization of cyber extension utilization to the extension worker.
\end{abstract}

Keywords : cyber extension, performance, agricultural extension, extension worker

JEL Classification: D80, Q16, Q18

\section{INTRODUCTION}

The extension methods such as newspapers, leaflets, radio and television that were conducted indirectly through conventional mass media had faced various challenges. Submission of extension materials through conventional media in the process of delivering agricultural information is sometimes still not on time, right place, target and not necessarily accepted by farmers. Today, the agricultural knowledge to overcome the problems faced by farmers are more varied, so that agricultural extension workers are required to be ready at any situation.

The appropriate strategy of information dissemination can improve farmers' ability to find information and change information dissemination (Ansari \& Sunetha, 2014). On the other hand, the

\footnotetext{
* Corresponding author email: sabirtato@gmail.com, ISSN 2615-6075 online; ISSN 2615-6946 print @UWG Press, 2018

OJS http://publishing-widyagama.ac.id/ejournalv2/index.php/jsed/
}

study of existing agricultural information needs is still dominated by the conventional information sources, communication technology-based information sources or ICTs (Mulyandari, Sumardjo, Lubis, \& Panjaitan, 2011).

Based on these conditions, Agency for Agricultural Extension and Human Resources Development (BPPSDMP) as the representative of the Ministry of Agriculture modified the formulation and dissemination of agricultural extension through internet-based network called cyber extension (Badan PPSDMP., 2010).

The existence of cyber extension can support the performance of agricultural extension both in enriching extension content and introducing it to farmers. In addition, cyber extension in Indonesia is extension information system through internet, to support provision extension material and agricultural information of extension workers in facilitating agribusiness learning process for main and business actors (Dzakiroh, Wibowo, \& Insaniyatin, 2017). The cyber extension is one of the effective mechanism for developing 
communication networks among farmers by implementing ICTs in the agricultural extension system.

The effectivity of agricultural information is one of the indicators in achieving the success of agricultural extension. The existence of cyber extension had brought both consequence and demand to agricultural extension workers to be more proactive. They were demanded to seek information as extension materials needed by farmers. According to Ahuja (2011), the availibility of agricultural information through internet (cyber extension) could improve agricultural extension process more quickly and effective.

On the other hand, Malang Raya's agricultural extension workers are still rely on printed media as information source for extension activity. This is due to the condition of Agricultural Extension Center that does not have computer facilities. It affects the performance of extension workers in utilizing online information.

According to Marliati et.al. (2008), the performance of agricultural extension workers are affected by both internal and external factors. The performance of extension workers are also reflected by the level of farmers' satisfaction who receive agricultural extension services. The competency of agricultural extension workers is one of the main factors expected to have an influence on their performance. The low competence of agricultural extension workers produces low performance as well (Kusmiyati et al., 2010) (Hidayat, 2009). External factors that are expected to influence the performance of the extension worker are social charecteristic system (ie. aspects which support/ inhibit changes in the social system as a result of the agricultural development policy).

In short, the objectives of this study are to describe the implementation of cyber extension and to analyze the performance of extension workers in the use of cyber extension in Malang Raya region.

\section{RESEARCH METHOD}

Malang Raya region was chosen as the research location. Sampling technique used in this research was purposive sampling, with the consideration that extension workers selected as respondents have a lot of experience. There were 30\% (87 people) of 288 agricultural extension workers in Malang Raya region selected as respondents.

The kind of data collected is primary data. Primary data were obtained through deep interview with questionnaire guidelines. Deep interview was conducted in order to gather complex information which contains opinions, attitudes and personal experiences. The primary data were based on the research variables. There are cyber extension implementation and the performance of agricultural extension worker used as research variables. Those variables consist of

a. the exsistence and activeness of cyber extension administrator,

b. the dialogue between agricultural extension workers and their counterparts,

c. the presence and involvement of agricultural extension workers in socialization meeting,

d. the factors of tracking information, responding to information, conveying ideas, utilizing cyber extension information, and introducing cyber extension to main players and business actors,

e. the performance of agricultural extension workers in utilizing cyber extension.

Those data were analized by using quantitative and qualitative analysis. Qualitative data are intended to complement the finding of quantitative analysis. Quantitative analysis in this research was conducted by using descriptive statistical analysis of Ms Excel. According to Sugiyono (2016) descriptive analysis is used to describe or give an overview of the research object through sample data or population as it is without analyzing and making generally accepted conclusions. To categorize respondents' answer, an interval scale was counted from the highest score (4) substracted by the lowest score (1) then the result was divided into four categories. The classification of respondents' answers was shown in Table 1

Table 1. The Determination of Score Categories

\begin{tabular}{lc}
\hline Scale of answer & Category \\
\hline $1.00-1.75$ & Very low \\
$1.76-2.50$ & low \\
$2.51-3.25$ & Moderate \\
$3.26-4.00$ & High \\
\hline
\end{tabular}

Sources: Sugiyono (2016) 


\section{RESULT AND DISCUSSION}

\section{Respondent Characteristics}

Malang Raya region has relatively great potency in agriculture. It is reflected in the extent of rice field in Malang Raya region which is 74.4 thousand ha. In terms of the number of agricultural extension workers, Malang Raya region has the potency for relatively large agricultural extension workers. The number of agricultural extension workers are 225 people (109 goverment extension workers and 116 contract-based extension workers, THL-TBPP) for Malang Regency, 34 people (21 goverment extension workers and 13 contractbased extension workers) for Malang City and 32 people (24 goverment extension workers and 8 contract-based extension workers) for Batu City. Those agricultural extension workers are assigned to disseminate agricultural informaion both in the form of the latest agricultural technology and superior seeds.

Table 2. The Demograpic Characteristics of Respondents

\begin{tabular}{lrc}
\hline Variable & $\begin{array}{c}\text { Number of } \\
\text { sample }\end{array}$ & $\begin{array}{r}\text { Percentage } \\
(\%)\end{array}$ \\
\hline Sex & 46 & 52.9 \\
a. Male & 41 & 47.1 \\
b. Female & & \\
Age & 22 & 25.3 \\
a. 25-33 years & 27 & 31.1 \\
b. 34-42 years & 9 & 10.4 \\
c. 43-51 years & 29 & 33.3 \\
d. 52-59 years & & \\
Education & 4 & 4.6 \\
a. Senior High School & 6 & 6.9 \\
b. DIII & 69 & 79.3 \\
c. Bachelor & 6 & 6.9 \\
d. Master & & \\
Rank and Group & 16 & 18.4 \\
a. Pembina/ Golongan IV & 51 & 58.6 \\
b. Penara/ Golongan III & 9 & 10.4 \\
c. Pengatur/ golongan II & 11 & 12.6 \\
d. Honorer & 0 & \\
Working period & 19 & 21.8 \\
a. 30-39 years & 10 & 11.5 \\
b. 21-29 years & 4 & 4.6 \\
c. 12-20 years & & \\
d. 3-11 years & & \\
\hline
\end{tabular}

Based on Table 2, male and female respondents respectively are 46 people (52.9\%) and 41 people (47.1\%). Furthermore, Table 1 shows that the majority of respondents that are 52-59 years old are 29 people $(33.3 \%)$, while the number of respondents in the age of 43-51 years old are 9 people (10.3\%).

Based on the education level, most of respondents i.e. 69 people (73.3\%) have graduate degree. Table 1 also shows that extension workers with the longest and the shortest working period respectively are 39 years and 4 years. Most respondents who have a working peiod of 3-11 years are $62.1 \%$ and are dominated by THL-TBPP respondents. Agricultural extension workers with a short working period indicate that they have higher motivation than agricultural extension workers with a long working period in using cyber extension as an extension media.

\section{Cyber Extension Implementation}

Based on the research results, most extension centers did not have administrator to manage cyber extension. It was due to several factors such as changes in Regional Goverment Agency (SKPD) which handles extension unit and the absence of assistance from BPPSDMP. The absence of administrator was confirmed by the research result that there was no adminsitrator (27.6\%) and there was less active administrator (58.6\%) (Table 3). It revealed that local goverment or central goverment (ministry of agriculture) was not serious to develop cyber extension. It was caused by administrator and server who were main factors influencing the success of cyber extension utilization (Praza, 2016).

Table 3. The Existence and Activeness of Cyber Extension Administrator

\begin{tabular}{lcc}
\hline Type of frequency & $\begin{array}{c}\text { Number of } \\
\text { respondent }\end{array}$ & $\begin{array}{c}\text { Percentage } \\
(\%)\end{array}$ \\
\hline Not exist & 24 & 27.6 \\
exist, less active & 51 & 58.6 \\
exist, active & 12 & 13.8 \\
exist, very active & 0 & 0.0 \\
\hline Total & 87 & 100.0 \\
\hline
\end{tabular}

In addition, Agricultural Extension Center generally did not have infrastructure such as computer, internet and etc. It is in accordance with the research conducted by Mulyandari (2011) who stated that there was generally no support from goverment to help agricultural extension workers or farmers to acces technology information. In other words, this condition was one of obstacles for utilizing a new technology (Amin et al., 2014). The availability of internet access also become the most 
important infrastructure to increase agricultural extension workers' performance. Those obstacles could detain agricultural development process.

The results also showed that the use of cyber extension was not yet fully utilized. This was due to the lack of socialization to agricultural extension workers. The lack of socialization was reflected in the socialization activity variable which get 2.11 out of 4.00. In other words, the cyber extension socialization was felt to be less intensive. The number was the average of some indicators such as dialouge, attendance, socialization presence, and motivation to attend socialization and socialization involvement.

From the dialogue aspect between agricultural extension workers and their counterparts about cyber extension, $37.9 \%$ respondents stated that they never had dialogue with their counterparts. Most respondents $(56.3 \%)$ told that they rarely had diologue with counterparts. It implied that most respondents tended to be less care about the existence of cyber extension (Table 4).

Table 4. The Frequency of Dialogue between Extension Workers and Other Counterparts

\begin{tabular}{lcc}
\hline Type of frequency & $\begin{array}{c}\text { Number of } \\
\text { respondent }\end{array}$ & $\begin{array}{c}\text { Percentage } \\
(\%)\end{array}$ \\
\hline Never & 33 & 37.9 \\
Rarely & 49 & 56.3 \\
Often & 5 & 5.8 \\
Always & 0 & 0.00 \\
\hline Total & 87 & 100 \\
\hline
\end{tabular}

From the aspect of the agricultural extension workers presence in socialization meeting, $32.2 \%$ and $42.5 \%$ respondents respectively stated that they never and rarely attended the socialization (Table 5). Meanwhile, 3.5\% respondents stated that they always attended the socialization meeting.

Table 5. The Frequency of Agricultural Extension Presence in Socialization Activity

\begin{tabular}{lcc}
\hline Type of frequency & $\begin{array}{c}\text { Number of } \\
\text { respondent }\end{array}$ & $\begin{array}{c}\text { Percentage } \\
(\%)\end{array}$ \\
\hline Never & 28 & 32.2 \\
Rarely & 37 & 42.5 \\
Often & 19 & 21.8 \\
Always & 3 & 3.5 \\
\hline Total & 87 & 100 \\
\hline
\end{tabular}

In relation to their involvement in cyber extension socialization, $16.1 \%$ of respondents stated that they had never been involved and $33.3 \%$ stated that they were rarely involved in the extension socialization (Table 6).

Table 6. The Involvement of Agricultural Extension Workers in Socialization Meeting

\begin{tabular}{lcc}
\hline Type of frequency & $\begin{array}{c}\text { Number of } \\
\text { respondent }\end{array}$ & $\begin{array}{c}\text { Percentage } \\
(\%)\end{array}$ \\
\hline Never & 14 & 16.1 \\
Rarely & 29 & 33.3 \\
Often & 35 & 40.2 \\
Always & 9 & 10.3 \\
\hline Total & 87 & 100 \\
\hline
\end{tabular}

The result showed that the low of socialization reflected by the socialization score was influenced by the internal factors of agricultural extension worker. The agricultural extension workers seem to have no motivation in utilizing cyber extension. This is in accodance with the statement of the Head of the Agricultural Extension center as one of the respondents in this study. He explained that daily visitor of cyber extension only reached approximately 200 visitors. That number was far from the total of Indonesia's agricultural extension workers which were around 40 thousand people. The factors limiting in utilizing cyber extension done by extension workers were the lack of integration between cyber extension with other agricultural techlogy providers such as Katam, Landsat, e-farm, etc. Furthermore, information technology expert in agricultural extension sector was still low, cyber extension display was less attractive and the content was less in line with the extension needs.

\section{Cyber Extension Performance}

Performance is the result or output of a process. According to behavioral approach in management, performance is the quantity or quality of something produced or services provided by someone who does the work.

The result of descriptive analysis revealed that the agricultural extension performance in utilizing cyber extension in Malang Raya region was still very low with an average score of 1.58 of 4.00 . The results were the average of several accessibility indicators such as (i) tracking information; (ii) responding to information; (iii) conveying ideas or 
questions; (iv) utilizing cyber extension information content as agricultural extension material; and (v) introducing cyber extension to main players and business actors. The research result of these elements are described descriptively as follows.

There were 26.4 and $54.0 \%$ respondents respectively who never and rarely searched information by using cyber extension (Table 7). This showed that most agricultural extension workers did not utilize cyber extension as extension material to farmers. Various reasons expressed by respondents regarding to the low utilization of cyber extensions such as some extension agents prefer to use the search engine www.google.com as it is convenience and more variety.

Table 7. The Frequency of Information Seeking Through Cyber Extension

\begin{tabular}{lcc}
\hline Type of frequency & $\begin{array}{c}\text { Number of } \\
\text { respondent }\end{array}$ & $\begin{array}{c}\text { Percentage } \\
(\%)\end{array}$ \\
\hline Never & 23 & 26.4 \\
Rarely & 47 & 54.0 \\
Often & 14 & 16.1 \\
Always & 3 & 3.4 \\
\hline Total & 87 & 100 \\
\hline
\end{tabular}

Furthermore, This study also showed that agricultural extension workers who were old enough (in the age over or same 50 years old) tend not to be able to access information through internet. They got the extension material from conventional media such as printed media. In addition, it was also due to limited availibility of infrastructure, including internet access in that region.

Agricultural extension worker performance from the aspect of giving feedback or response to agricultural information through cyber extension was also classiffied as less optimal. Based on Table 8 , it is shown that most respondents (50.6\%) never responded to information through cyber extension. It implied that there was no curiosity from agricultural extension workers about cyber extension.

The lack of understanding of how to respond or give feedback on the information through cyber extension was a contributing factor why it happened. Another factor that caused the low of agricultural extension performance was the absence of goverment policies which enforced them to utilize cyber extension.

Table 8. The Frequency of Responding Toward Cyber Extension

\begin{tabular}{lcc}
\hline Type of frequency & $\begin{array}{c}\text { Number of } \\
\text { respondent }\end{array}$ & $\begin{array}{c}\text { Percentage } \\
(\%)\end{array}$ \\
\hline Never & 44 & 50.6 \\
Rarely & 33 & 37.9 \\
Often & 10 & 11.5 \\
Always & 0 & 0.0 \\
\hline Total & 87 & 100 \\
\hline
\end{tabular}

Agricultural extension workers in Malang Raya Region had not conducted the dissemination of appropriate agricultural innovation and technology seen from the results of personal studies or experiences through cyber extension. It was depicted that most respondents $(67.8 \%)$ never disseminated extension material through cyber extension (Table 9).

Table 9. The Frequency of Conveying Information or Question Frequency through Cyber Extension

\begin{tabular}{lcc}
\hline Type of frequency & $\begin{array}{c}\text { Number of } \\
\text { respondent }\end{array}$ & $\begin{array}{c}\text { Percentage } \\
(\%)\end{array}$ \\
\hline Never & 59 & 67.8 \\
Rarely & 19 & 21.8 \\
Often & 9 & 10.3 \\
Always & 0 & 0.00 \\
\hline Total & 87 & 100 \\
\hline
\end{tabular}

These conditions reflect the consequences that the respondents did not understand about utilizing cyber extension. In other word, the lack of understanding of utilization also affects the level of dissemination of innovation and appropriate technology conducted by respondents.

The performance of agricultural extension workers in terms of utilizing cyber extension as extension material is still classified as less optimal. The descriptive analysis result showed that agricultural extension worker who used technology information obtained through cyber extension as the main material for agricultural extension is $34.5 \%$ and said rarely, and $57.5 \%$ had never been done (Table 10).

In general, they were more likely to use material obtained from other information sources such as print media, interpersonal communication, scientific publications and google. This is consistent with the result of a previous study conducted by 
Anwas, Sumardjo, Asngari, \& Tjitropranoto (2009) who suggested that the most widely used source of infomation by agricultural extension worker in Bogor Regency was interpersonal sources and printed media (newspapers).

Table 10. The Frequency of Utilizing Information Content through Cyber Extension as Agricultural Extension Material

\begin{tabular}{lcc}
\hline Type of frequency & $\begin{array}{c}\text { Number of } \\
\text { respondent }\end{array}$ & $\begin{array}{c}\text { Percentage } \\
(\%)\end{array}$ \\
\hline Never & 50 & 57.5 \\
Rarely & 30 & 34.5 \\
Often & 7 & 8.1 \\
Always & 0 & 0.0 \\
\hline Total & 87 & 100 \\
\hline
\end{tabular}

The results of descriptive analysis showed that the introduction of cyber extension to main and business actors was classified as not optimal with an avrage score of 1.51 from a maximum score of 4.00. Agricultural extension worker who stated that they had never and rarely introduced cyber extension to both main and business actors were $52.9 \%$ and $40.2 \%$ respectively (Table 11 ).

Table 11. The Frequency of Introducing Cyber Extension by Agricultural Extension Workers

\begin{tabular}{lcc}
\hline Type of frequency & $\begin{array}{c}\text { Number of } \\
\text { respondent }\end{array}$ & $\begin{array}{c}\text { Percentage } \\
(\%)\end{array}$ \\
\hline Never & 46 & 52.9 \\
Rarely & 35 & 40.2 \\
Often & 6 & 6.9 \\
Always & 0 & 0.0 \\
Total & 87 & 100 \\
\hline
\end{tabular}

\section{Implication for improving the agricultural extension worker performance}

Agricultural extension workers act as innovator, facilitator, consultant and communicator. The importance of this role requires agricultural extension workers to be able to always increase their capacity, especially in enriching extension materials. Pramono, Fatchiya, \& Sadono (2017) stated that this condition certainly required the needs of agricultural extension workers who had competence based on the knowledge and skills according to their perspective fields. The process of increasing capacity can be done through internet search engine like google.

The random process of agricultural information seeking had weaknesses. Based on Law Number 16 of 2006 concerning extension system states that extension material converyed both to main and business actors must obtain recommendation from goverment institution, except for techlogical sourced from traditional knowledge. This indicates that the materials have not all been verified by goverment intstitution, so if there is a loss experienced by farmers, agricultural extension workers can be sued.

Therefore, the presence of cyber extension can accommodate the demand of fulfilling the competency of agricultural extension workers. Beside being able to ensure that the extension material obtained by agricultural extension workers through cyber extension have been verified, it also can help agricultural extension to do efficiently. Ahuja (2011) also added that the availibility of information through the internet (cyber extension) helps agricultural extension process more quickly and effectively. In addition, it is expected that agricultural extension workers are expected to routinely update their knowledge regarding agricultural extension regulations.

The various facilities offered by cyber extension do not seem to be fully understood by agricutural extension workers. This is indicated by the results of this study, where the performance of agricuultural extension workers in utilizing cyber extension is still low. Those conditions is depicted as still low of agricultural information seeking through cyber extension, responding to information, conveying ideas or questions, utilizing cyber extension information content as agricultural extension materials and introducing cyber extension to main and business actors.

The low of utilization of cyber extension generally come from internal factors. One of the conditions is reflected in the low motivation of agricultural extension workers in terms of cyber extension implementation variable. Amin et.al. (2013) stated that the effectiveness of cyber extension use is greatly affected by interaction and perception.

Based on those conditions, there are some efforts that should be implemented to optimize the use of cyber extension such as:

1. Doing socialization of the importance verified agricultural extension materials based on Law Number (No). 16 of 2006 concerning extension 
system. Moreover, the existence of cyber extension can help agricultural extension workers in utilizing information that can be accounted for. This can be a motivation for agricultural extension workers to utilize cyber extension.

2. Mentoring especially for agricultural extension workers who have dificulty in using internet.

3. Facilitating the intitutions which handle agricultural extension workers with cyber extension devices such as computers and internet network.

4. Adding special budget done by Ministry of Agriculture for improving cyber extension utilization such as giving reward for agricultural extension workers who actively convey their extension material through cyber extension.

5. Desseminating the utilization of cyber extension to agricultural extension workers through regular meetings at extension institution such as Agricultural Extension Center (BPP).

\section{ACKNOWLEDGEMENT}

We would like to thank to the Doctoral Program of Agricultural Science, University of Brawijaya. Besides that, we would also like to thank to the Agricultural Training Center Jambi and all respondents for supporting in collecting the data.

\section{CONCLUSION AND SUGGESTION}

This study shows that agricultural extension workers have not fully implemented the cyber extension. This is due to the lack of socialization to agricultural extension. The lack of socialization was reflected on the value of socialization variable which was 2.11 of 4.00 .

In addition, the performance of agricultural extension in Malang Raya regency was 1.58 of the maximum score of 4.00 . It reflected that agricultural extension workers in Malang raya region have low performance of utilizing cyber extension. There are some conditions influenced by several accessibility indicators, namely: (i) tracking information, (ii) responding to information, (iii) conveying ideas or questions, (iv) utilizing the information content of cyber extension as agricultural extension material, and (v) introducing cyber extension to the main actors and businesses.

Based on the performance implications, the goverment can take several actions such as:

1. Doing socialization of the improtance verified agricultural extension material based on Law Number (No). 16 of 2006 concerning extension system.

2. Mentoring agricultural extension workers who have dificulty in using internet.

3. Facilitating the intitutions which handle agricultural extension workers with cyber extension devices such as computers and internet network.

4. Adding special budget done by Ministry of Agriculture for improving cyber extension utilization such as giving reward for agricultural extension workers who actively convey their extension material through cyber extension.

5. Desseminating the utilization of cyber extension to agricultural extension workers through regular meetings at extension institution such as Agricultural Extension Center (BPP).

\section{REFERENCES}

Ahuja, V. (2011). Cyber Extension: a Convergence of Ict and Agricultural Development. Global Media Journal, 2(2), 1-8. Retrieved from http://www.caluniv.ac.in/global-mdiajournal/Winter Issue December 2011 Commentaries/C-6 Ahuja.pdf

Amin, M., Pengkajian, B., Pertanian, T., Tengah, S., Laosos, J., \& Sigi, B. (2014). Effectiveness And Farmer's Behavior In Using Information Technology Based On Cyber Extension. Informatika Pertanian, 23(2), 211-219. https://dx.doi.org/10.21082/ip.v23n2.2014.p21 $\underline{1-219}$

Amin, M., Sugiyanto, Sukesi, K., \& Ismadi. (2013). Application of Cyber Extension as Communication Media to Empower the Dry Land Farmer at Donggala District, Central Sulawesi. J. Basic. Appl. Sci. Res, 3(4), 379$385 . \quad$ Retrieved from https://www.textroad.com/pdf/JBASR/J.\%20Ba sic.\%20Appl.\%20Sci.\%20Res.,\%203(4)379385,\%202013.pdf

Ansari, M. A., \& Sunetha, S. (2014). Agriculture Information Needs of Farm Women: A study in State of north India. African Journal of 
Agricultural Research, 9(19), 1454-1460. https://doi.org/10.5897/AJAR2014

Anwas, E. O. M., Sumardjo, Asngari, P. S., \& Tjitropranoto, P. (2009). Faktor-Faktor yang Mempengaruhi Penyuluh dalam Pemanfaatan Media. Juli, 7(2), 68-81. Retrieved from http://journal.ipb.ac.id/index.php/jurnalkmp/arti cle/download/5689/4317

Badan PPSDMP. (2010). Grand Design Sistem Informasi Penyuluhan Pertanian (Cyber Extension). Jakarta.

Dzakiroh, D., Wibowo, A., \& Ihsaniyatin, H. (2017). Sikap Afektif Penyuluh terhadap Website Cyber Extension sebagai Sumber Informasi Penyuluhan Pertanian di Kabupaten Karanganyar. Jurnal Agritexts, 4(1), 16-31. Retrieved from https://jurnal.uns.ac.id/ja/article/download/180 $\underline{58 / 14382}$

Hidayat, S. I. (2009). Analisis Kinerja Penyuluh Pertanian di Wilayah Kerja Unit Penyuluhan Pertanian Sukodono, Sidoarjo. Jurnal Habitat, 20(1), 45-56. Retrieved from http://habitat.ub.ac.id/index.php/habitat/index

Kusmiyati, O. :, Maryani, A., Kusnadi, D., Stpp, D., Jurusan, B., \& Pertanian, P. (2010). Kinerja Penyuluh Pertanian PNS dalam Melaksanakan Tupoksi di Kabupaten Bogor (Kasus di BP3K Cibungbulang). Jurnal Penyuluh Pertanian, 5(1), 87-103. Retrieved from https://anzdoc.com/kinerja-penyuluh-pertanianpns-dalam-melaksanakan-tupoksi-di.html

Marliati, Sumardjo, Asngari, P., Tjitropranoto, P., \& Saefuddin, A. (2008). Faktor-Faktor Penentu Peningkatan Kinerja Penyuluh Pertanian Dalam Memberdayakan Petani (Kasus di Kabupaten Kampar Provinsi Riau). Jurnal Penyuluhan, 4(2),
90-99.

https://dx.doi.org/10.25015/penyuluhan.v4i2.21 $\underline{74}$

Mulyandari, R. S. . (2011). Perilaku Petani Sayuran dalam Memanfaatkan Teknologi Informasi. Jurnal Perpustakaan Pertanian. Jurnal Perpustakaan Pertanian, 20(1), 22-34. Retrieved from https://anzdoc.com/perilakupetani-sayuran-dalam-memanfaatkan-teknologiinforma.html

Mulyandari, Sumardjo, Lubis, D. P., \& Panjaitan, N. K. (2011). Cyber extension as a communications media for vegetable farmer Empowerment. Journal of Agricultural Extension and Rural Development, 4(3), 77-84. Retrieved from

https://academicjournals.org/journal/JAERD/arti cle-abstract/43C25302914

Pramono, H., Fatchiya, A., \& Sadono, D. (2017). Kompetensi Penyuluh Tenaga Harian Lepas Tenaga Bantu Penyuluh Pertanian di Kabupaten Garut, Jawa Barat. Jurnal Penyuluhan, 13(2), 194-209.

https://dx.doi.org/10.25015/penyuluhan.v13i2.1 $\underline{6128}$

Praza, R. (2016). Optimalisasi Cyber Extension dalam Pembangunan Pertanian di Era MEA. In Prosiding Seminar Nasional BKS PTN Wilayah Barat Bidang Ilmu Pertanian. (pp. 200-204). Lhokseumawe : Univ. Malikussaleh. Retrieved from

http://repository.unimal.ac.id/2913/1/Optimalis asi Cyber Extension Dalam Pembangunan.pdf

Sugiyono. (2016). Metode Penelitian Kuantitatif Kualitatif dan R and D (23rd ed.). Alfabeta, Bandung. 